\title{
Fear conditioning enhances spontaneous AMPA receptor-mediated synaptic transmission in mouse hippocampal CA1 area
}

\author{
Ming Zhou, ${ }^{1}$ Lisa Conboy, ${ }^{2}$ Carmen Sandi, ${ }^{2}$ Marian Joëls ${ }^{1}$ and Harm J. Krugers ${ }^{1}$ \\ ${ }^{1}$ Swammerdam Institute for Life Sciences, Center for Neuroscience, Science Park 9041098 XH, Amsterdam, The Netherlands \\ ${ }^{2}$ Brain Mind Institute, Ecole Polytechnique Federale de Lausanne, Lausanne, Switzerland
}

Keywords: AMPA, CA1, fear conditioning, hippocampus, memory, mEPSCs

\begin{abstract}
AMPA receptor-mediated synaptic modifications in the amygdala have been reported to sustain cued fear conditioning. However, the hippocampal formation is also critically involved in fear learning. Therefore, we examined whether fear conditioning is also accompanied by changes in AMPA receptor-mediated synaptic transmission in the hippocampus. We focused on spontaneous miniature excitatory post-synaptic currents (mEPSCs). Young adult mice were trained using tone/footshock pairings and contextual/cued memories were tested $3-4 \mathrm{~h}$ and 1 day later. We found that the mEPSC frequency was significantly enhanced when recorded $3 \mathrm{~h}$, but not $24 \mathrm{~h}$, after fear conditioning training. Fear training induced a slight enhancement in the mEPSC amplitude at $3 \mathrm{~h}$ after training. The increased mEPSC frequency and amplitude were absent in animals that were only exposed to footshock or novelty or unpaired tone/footshock training. This implies that learning the association between context, tone and footshock transiently enhances hippocampal CA1 spontaneous synaptic transmission, which may contribute to the encoding of the fearful event.
\end{abstract}

\section{Introduction}

Long-term potentiation (LTP) reflects an increase in synaptic efficacy and it is believed that such changes in synaptic weight underlie learning and memory processes (Neves et al., 2008). Indeed, LTP-like changes have been reported in the hippocampal CA1 area after passive avoidance training and in the lateral amygdala after fear conditioning (Rogan et al., 1997; Whitlock et al., 2006), and mechanisms maintaining LTP sustain spatial memory (Pastalkova et al., 2006).

Long-term potentiation involves the activity-dependent recruitment of AMPA receptors to the post-synaptic membrane and a concurrent increase in AMPA-mediated transmission (Malinow \& Malenka, 2002; Plant et al., 2006). Recent studies demonstrated not only that LTP is associated with a rapid delivery of AMPA receptors but that fear conditioning requires delivery of AMPA receptors to synapses of post-synaptic neurons in the lateral amygdala (Rumpel et al., 2005). Earlier it was shown that cued fear conditioning, a strong form of associative learning, is accompanied by enhanced glutamatergic transmission in subnuclei of the amygdala (McKernan \& ShinnickGallagher, 1997; Tsvetkov et al., 2002; Humeau et al., 2007).

However, behavioral studies suggest that not only the amygdala but also the hippocampus is critically involved in fear conditioning, especially with regard to contextual aspects (LeDoux, 2000; Sanders et al., 2003; Maren, 2008). Genetic deletion studies (Rampon et al.,

Correspondence: Dr Ming Zhou, as above.

E-mail: m.zhou@uva.nl

Received 25 November 2008, revised 19 August 2009, accepted 19 August 2009
2000) support an important role for the CA1 area. Moreover, after cued fear conditioning, the synchronization of rhythmical activity at theta frequencies in the lateral amygdala and hippocampal CA1 area increases (Seidenbecher et al., 2003), suggesting that interactions between both regions might be critical to establish fearful memories. We therefore examined in detail whether fear learning alters synaptic efficacy in the hippocampal CA1 area. To this end we recorded AMPA receptor-mediated synaptic transmission in hippocampal CA1 neurons at different time-points after fear conditioning, focusing on spontaneous miniature excitatory synaptic currents (mEPSCs).

\section{Materials and methods}

\section{Animals}

Male C57 black 6 mice (6-8 weeks old, Harlan, the Netherlands) were individually housed upon arrival in enriched cages for at least 1 week, with a light/dark cycle of $12 \mathrm{~h}$ (lights on at 08:00 h; room temperature kept around $20^{\circ} \mathrm{C}$ ). Food and water were given without restriction. The experiments were carried out in accordance with and approved by the local Animal Committee of the University of Amsterdam.

\section{Fear conditioning}

Animals were trained in a fear-conditioning chamber $(30 \mathrm{~cm} \times$ $24 \mathrm{~cm} \times 26 \mathrm{~cm}, \mathrm{~W} \times \mathrm{L} \times \mathrm{H})$. The grid floor was made of 37 stainless-steel rods and was connected to a shock generator 
(Med-Farm LION-ELD) that was developed in-house. On day 1 (08:30-09:00 h) one mouse at a time was trained in the footshock chamber (cleaned with $1 \%$ acetic acid). The animal was allowed to freely explore the chamber for $3 \mathrm{~min}$. This was followed by three tone/footshock pairs (with an interval of $1 \mathrm{~min})$. Each tone $(100 \mathrm{~dB}$, $2.8 \mathrm{kHz})$ lasted for $30 \mathrm{~s}$, accompanied by a footshock $(0.8 \mathrm{~mA})$ during the last $2 \mathrm{~s}$ and the mouse was taken back to its home cage $30 \mathrm{~s}$ after the end of the last pairing. We followed the three-trial rather than a single-trial fear-conditioning paradigm to strengthen fearful learning and reduce the variability in fear memory. Freezing behavior during this training session was scored before the onset of the first tone and after the end of each tone/footshock. At either 3 or $24 \mathrm{~h}$ after training, mice from separate groups were introduced into the same chamber and freezing behavior was scored for 3 min (contextual memory test). One hour later, animals were introduced into another chamber with a different contextual background (cleaned with $70 \%$ ethanol). After free exploration for $3 \mathrm{~min}$ the animal was exposed to one $(30 \mathrm{~s})$ tone without footshock and freezing behavior was scored before and during the tone presence (tone cue memory test). Mice in a novelty control group were introduced into the footshock chamber for $7 \mathrm{~min}$ without receiving any tone or footshock. Mice in the shock-only group received three footshocks ( $2 \mathrm{~s}$ intervals) immediately after being put into the chamber, after which they were immediately placed back in their home cages. In a separate post-hoc experiment animals received training of 3 pairs of tone and footshock (same intensity and duration as mentioned before) in an explicitly unpaired fashion before being subjected to mEPSCs recording.

Freezing behavior was determined for each $2 \mathrm{~s}$ throughout the experiment. Freezing was defined as no body movements except those related to respiration. The percentage of freezing time vs. total experimental time was used for statistical analysis.

\section{Electrophysiology}

At 3 or $24 \mathrm{~h}$ after training (in animals not subjected to a behavioral retrieval test), mice were decapitated (between 09:00 and 11:30 h). Dorsal hippocampal slices $(350 \mu \mathrm{m})$ were made on a vibratome (LEICA VT 1000S, Germany) and stored in normal artificial cerebrospinal fluid (aCSF) [containing (in $\mathrm{mM}$ ): $120 \mathrm{NaCl}, 3.5 \mathrm{KCl}$, $1.3 \mathrm{MgSO}_{4}, 1.25 \mathrm{NaH}_{2} \mathrm{PO}_{4}, 2.5 \mathrm{CaCl}_{2}, 10.0$ glucose and 25.0 $\mathrm{NaHCO}_{3}, \mathrm{pH}$ 7.4] and continuously gassed (mixture of $95 \% \mathrm{O}_{2} / 5 \%$ $\mathrm{CO}_{2}$ ) at room temperature for $>1 \mathrm{~h}$. One slice at a time was placed in a recording chamber mounted on an upright microscope (Nikon E600FN), continuously perfused with aCSF $\left(32^{\circ} \mathrm{C}, 2-3 \mathrm{~mL} / \mathrm{s}\right)$ and kept fully submerged. After the debris on the surface of the CA1 cell layer was removed with a cleaning pipette, whole-cell patch-clamp recordings were made using an AXOPATCH 200B amplifier (Axon Instruments, USA) with electrodes made from borosilicate glass (1.5 mm outer diameter, Hilgerberg, Malsfeld, Germany). The pipette solution contained (in mM): $120 \mathrm{Cs}$ methane sulfonate, $17.5 \mathrm{CsCl}, 10$ HEPES, 5 BAPTA, 2 Mg-ATP, 0.5 Na-GTP, 10 QX-314, pH 7.4, adjusted with $\mathrm{CsOH}$; pipette resistance was between 3 and $6 \mathrm{M} \Omega$. Under visual control $(40 \times$ objective and $10 \times$ ocular magnifications $)$ the electrode was directed towards a CA1 neuron with positive pressure. Once sealed on the cell membrane (resistance above $1 \mathrm{G} \Omega$ ) the membrane patch under the electrode was ruptured by gentle suction and the cell was kept at a holding potential of $-70 \mathrm{mV}$. The liquid junction potential caused a shift of no more than $10 \mathrm{mV}$, which was not compensated during mEPSC recording. Recordings with an uncompensated series resistance of $<15 \mathrm{M} \Omega$ and $<2.5 \times$ the pipette resistance with a shift of $<20 \%$ during the recording were accepted for analysis. Data acquisition was performed with PCLAMP 8.2 and analysed off-line with MINIANALYSIS (version 6.0.9).

Miniature excitatory post-synaptic currents were recorded at a holding potential of $-70 \mathrm{mV}$ as described before (Karst \& Joels, 2005). Tetrodotoxin $(0.25 \mu \mathrm{M}$, Latoxan, Rosans, France) and bicuculline methobromide $(20 \mu \mathrm{M}$, Biomol) were added to the buffer to block action potential-induced glutamate release and $\mathrm{GABA}_{\mathrm{A}}$ receptor-mediated miniature inhibitory post-synaptic currents, respectively. During some recordings the non-N-methyl-D-aspartate receptor blocker 6-cyano-7-nitroquinoxaline-2,3-dione (10 $\mu \mathrm{M}$, Tocris) was perfused to confirm that the mEPSCs were indeed mediated by AMPA receptors. The events were examined manually and identified as mEPSCs when the rise time was faster than the decay time, with an event detection threshold of $-5 \mathrm{pA}$. mEPSCs were recorded for $5 \mathrm{~min}$ in each cell. The frequency and peak amplitude of mEPSCs of all cells were determined.

\section{Biochemistry}

Hippocampi from naive and fear-conditioned mice $(3$ or $24 \mathrm{~h}$ after training) were isolated and stored at $-80^{\circ} \mathrm{C}$. For preparation of synaptoneurosomes, tissue samples were homogenized in ice-cold homogenization buffer (10 mM HEPES, $1.0 \mathrm{~mm}$ EDTA, $2.0 \mathrm{~mm}$ EGTA, $0.5 \mathrm{mM}$ dithiothreitol, $0.1 \mathrm{~mm}$ phenylmethanesulfonyl fluoride, $10 \mathrm{mg} / \mathrm{L}$ leupeptin, $100 \mathrm{nM}$ microcystin) with an Eppendorf homogenizer and homogenates were passed through two $100-\mu \mathrm{m}$-pore nylon mesh filters. At this stage, aliquots of whole hippocampus were taken and stored at $-80^{\circ} \mathrm{C}$ for future analysis. The remaining tissue was passed through two further 5 - $\mu \mathrm{m}$-pore filters. Filtered homogenates were centrifuged at $3600 \mathrm{~g}$ for $10 \mathrm{~min}$ at $4^{\circ} \mathrm{C}$. Resultant pellets were resuspended in $100 \mu \mathrm{L} 1 \%$ sodium dodecyl sulfate, boiled for $10 \mathrm{~min}$ and stored at $-80^{\circ} \mathrm{C}$.

Whole and synaptoneurosome hippocampal samples were quantified using the detergent-compatible protein assay (Biorad). Equal protein samples were prepared at a concentration of $0.5 \mu \mathrm{g} / \mathrm{mL}$ in $33 \mathrm{mM}$ $\mathrm{NaCl}, 70 \mathrm{~mm}$ Tris- $\mathrm{HCl}, 1 \mathrm{~mm}$ EDTA, 2\% (w/v) sodium dodecyl sulfate, $0.01 \%(\mathrm{w} / \mathrm{v})$ bromophenol blue and $10 \%$ glycerol, $\mathrm{pH} 6.8$. Proteins were resolved on $10 \%$ polyacrylamide gels and transferred to nitrocellulose membranes. Membranes were blocked for $1 \mathrm{~h}$ at room temperature with 5\% non-fat dry milk in Tris-buffered saline (TBS)$0.1 \%$ Tween 20. Membranes were then incubated with primary antibody glutamate receptor 2 (GluR2, $1: 2000$, AbCAM; GluR1, $1: 10$ 000, Assay Design; GluR3, 1: 1000, InVitrogen; pan-actin $1: 20000$, Sigma) for $2 \mathrm{~h}$ at room temperature. The membranes were washed three times in TBS- $0.1 \%$ Tween 20 for $10 \mathrm{~min}$ and then incubated overnight at $4{ }^{\circ} \mathrm{C}$ with the appropriate secondary horseradish peroxidase-linked antibodies diluted in blocking buffer. Following membrane washing with TBS- $0.1 \%$ Tween 20 buffer, the immunocomplexes were visualized using a chemiluminescence peroxidase substrate (SuperSignal West Dura Extended Duration Substrate) and immunoreactivity detected using the ChemiDoc XRS system (Biorad). Densitometry analysis on the bands was calculated using Quantity One 4.2.3 software (Biorad Laboratories AG, Switzerland). Each band was normalized to the actin level determined in the corresponding sample. On each gel at least two naive controls were used and protein changes were represented as a percentage of the normalized naive value. Care was taken to be in the linear range for all immunoblot assays.

\section{Data analysis}

Data are expressed as mean \pm SEM. Behavioral observations were analysed using repeated-measures ANOVA or two-tail paired- or 
independent-samples $t$-test. Electrophysiological and biochemical data were analysed using independent-samples $t$-test or one-way ANOVA followed by post-hoc Tukey and/or LSD test. Analysis was performed in SPSS 11.0 for windows. A $P$ value of $=0.05$ was set as the level of significance.

\section{Results}

\section{Fear conditioning}

Freezing behavior during training progressively and significantly increased after the end of each pair of tone and footshock (Fig. 1A, repeated-measures ANOVA, within-subject effect, $F_{3,105}=60.924$, $P<0.001)$. At 3 or $24 \mathrm{~h}$ later, when contextual memory was tested for $3 \mathrm{~min}$, animals displayed freezing behavior (Fig. 1B; fear conditioning $(\mathrm{FC}) / 3 \mathrm{~h}, 29.4 \pm 6.9 \%$ of total time, $n=7 ; \mathrm{FC} / 24 \mathrm{~h}$, $44.5 \pm 5.0 \%$ of total time, $n=6$ ) and significantly more when compared with the $3 \mathrm{~min}$ free exploration prior to the exposures of tone/shock pairs during training (paired-samples $t$-test: $\mathrm{FC} / 3 \mathrm{~h}$, $\left.t_{6}=4.235, P=0.005 ; \mathrm{FC} / 24 \mathrm{~h}, t_{5}=8.841, P<0.001\right)$, when animals showed no freezing at all. Although the total amount of contextual freezing over 3 min was not significantly different between animals that were tested at 3 or $24 \mathrm{~h}$ after training (Fig. $1 \mathrm{~B}, t_{11}=1.715, P=0.114$ ), contextual memory in the $3 \mathrm{~h}$ group was significantly less stable when compared with the $24 \mathrm{~h}$ group (Fig. 1C, repeated-measures ANOVA, time*treatment effect, $\left.F_{1,11}=9.204, P=0.011\right)$. Novelty $\left(t_{6}=4.235\right.$, $P=0.005)$ or shock-only $\left(t_{14}=3.861, P=0.007\right)$ control groups showed significantly less freezing behavior than the $\mathrm{FC} / 3 \mathrm{~h}$ group (Fig. 1B). During the tone cue test, compared with the free exploration period, animals displayed significant freezing behavior when the tone was applied (Fig. 1D, repeated-measures ANOVA, within-group effect, $\left.F_{1,10}=359.902, P<0.001\right)$ and no difference was found between the 3 and 24 h groups (between-group effect, $F_{1,10}=0.137, P=0.719$ ).

\section{Miniature excitatory post-synaptic current recordings after fear conditioning}

We next addressed the question of whether spontaneous AMPA receptor-mediated synaptic events in the CA1 area (an area essential
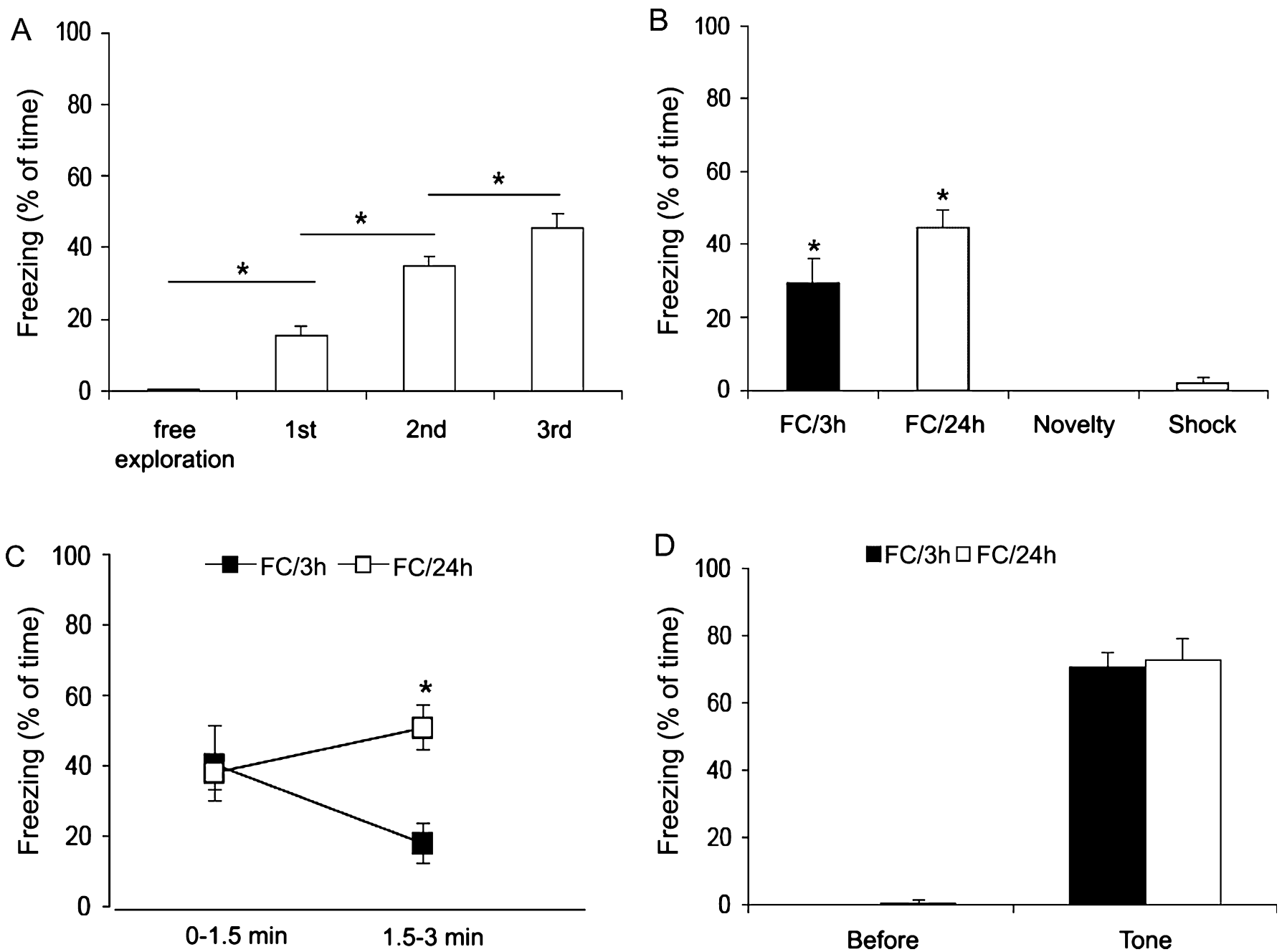

FIG. 1. Fear conditioning. (A) Acquisition. Tone/shock pairings progressively and significantly increased freezing behavior. Before, 3 min free exploration period; $1 \mathrm{st}, 2 \mathrm{nd}$ and $3 \mathrm{rd}, 30 \mathrm{~s}$ after the end of the 1st, 2 nd and 3rd pairs of tone and footshock, respectively $(n=36)$. (B) Context memory test. Moderate freezing behavior was observed in $3 \mathrm{~min}$ at both $3 \mathrm{~h}(\mathrm{FC} / 3 \mathrm{~h})$ and $24 \mathrm{~h}(\mathrm{FC} / 24 \mathrm{~h})$ after training, whereas no contextual freezing was observed in animals from novelty and shock groups. (C) Context memory. At $24 \mathrm{~h}$ after training (FC/24 h) animals show more freezing during the last $1.5 \mathrm{~min}$ of the total of 3 min of testing when compared with animals tested at $3 \mathrm{~h}$ after training (FC/3 h). (D) Tone cue memory test. Animals showed significantly more freezing upon tone exposure when compared with the free exploration period. $* P<0.05$. 
A

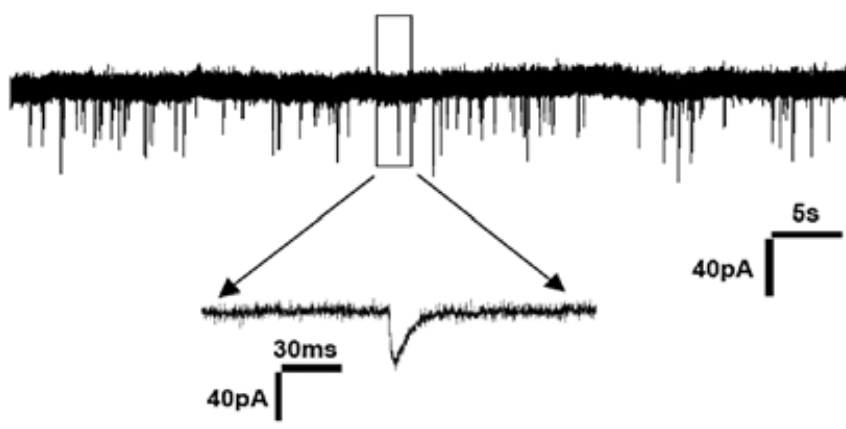

B

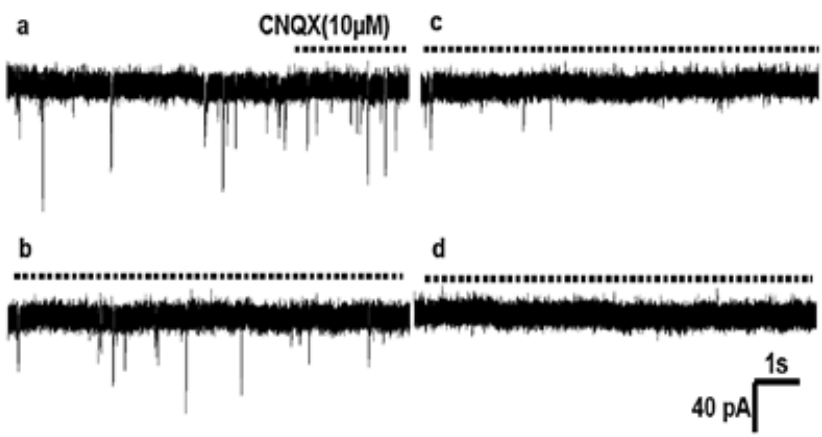

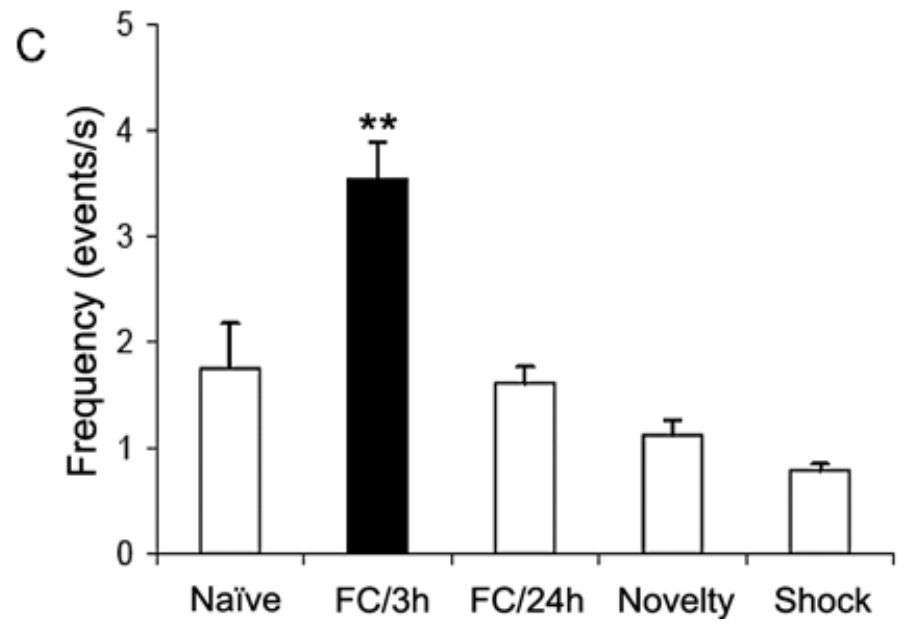

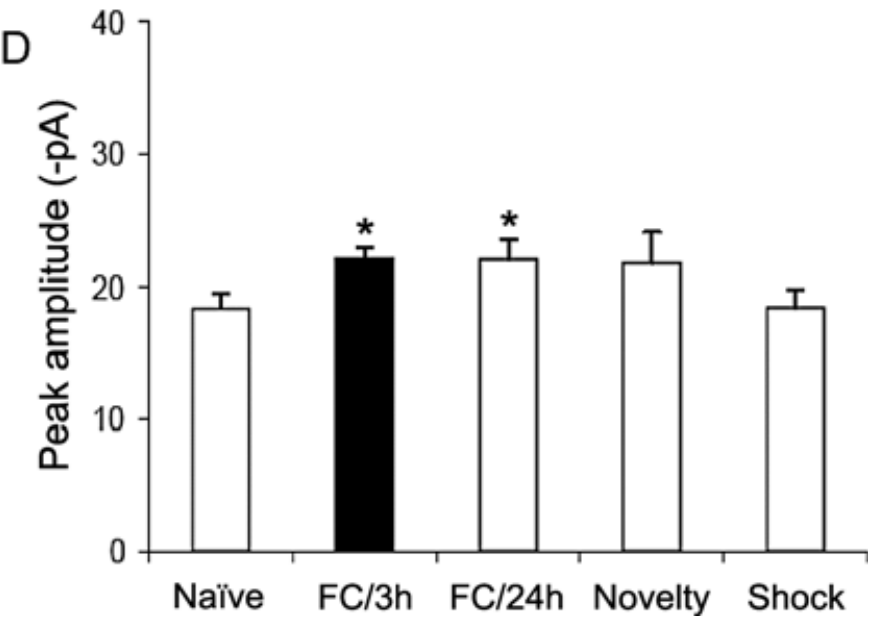

FIG. 2. mEPSC recordings in hippocampal CA1 area. (A) Typical example of mEPSC recordings in hippocampal CA1 area. (B) mEPSCs gradually disappear within $5 \mathrm{~min}$ (traces a-d) during the application of 6-cyano-7-nitroquinoxaline-2,3-dione (CNQX) (10 $\mu \mathrm{M})$. (C) $\mathrm{mEPSC}$ frequency at $3 \mathrm{~h}$ (FC/3 h) after training was significantly enhanced compared with the $\mathrm{FC} / 24 \mathrm{~h}$ group as well as naive, shock and novelty groups. (D) $\mathrm{mEPSC}$ peak amplitude in both $\mathrm{FC} / 3 \mathrm{~h}$ and $\mathrm{FC} / 24 \mathrm{~h}$ groups was slightly enhanced compared with naive control. $* * P<0.01, * P<0.05$.

for contextual fear conditioning) were altered in parallel with associative learning. To this end, animals were first trained and then decapitated 3 or $24 \mathrm{~h}$ later (i.e. in the absence of any retention trials); we also included the naive, novelty and shock control groups (six to eight cells per group). A typical example of an mEPSC recording is shown in Fig. 2A. mEPSCs were completely blocked by application of the non-N-methyl-D-aspartate receptor antagonist 6-cyano-7-nitroquinoxaline-2,3-dione $(10 \mu \mathrm{M}, \quad n=3$; Fig. 2B), supporting the idea that the mEPSCs indeed represented spontaneous AMPA-type glutamate receptor (AMPAR)-mediated synaptic events.

A transient enhancement of the mean frequency (events/s) of mEPSCs was found in animals tested at 3 but not $24 \mathrm{~h}$ after training (Fig. $2 \mathrm{C}$, one-way ANOvA, $F_{2,16}=10.838, P=0.001$ ). A post-hoc Tukey test revealed significant differences between $\mathrm{FC} / 3 \mathrm{~h}$ and naive groups $(P=0.004), \mathrm{FC} / 3 \mathrm{~h}$ and $\mathrm{FC} / 24 \mathrm{~h}$ groups $(P=0.002)$ but not between naive and $\mathrm{FC} / 24 \mathrm{~h}$ groups $(P=0.956)$. The $\mathrm{mEPSC}$ frequency was significantly lower in the novelty $\left(t_{12}=6.441\right.$, $P<0.001)$ and footshock groups $\left(t_{13}=7.746, P<0.001\right)$ compared with the $\mathrm{FC} / 3 \mathrm{~h}$ group, suggesting that the increase of $\mathrm{mEPSC}$ frequency in the $\mathrm{FC} / 3 \mathrm{~h}$ group was related to associative learning and not merely to the stress of the environment or exposure to footshocks. No differences were found between naive-novelty groups $\left(t_{11}=1.514\right.$, $P=0.158)$ or naive-footshock groups $\left(t_{12}=2.263, P=0.071\right)$.

In contrast to the change in mEPSC frequency, a trend towards significance was found in mean mEPSC peak amplitude (Fig. 2D, one-way ANOVA, $\left.F_{2,17}=2.966, P=0.079\right)$, where a post-hoc LSD test revealed significant differences between naive-FC $/ 3 \mathrm{~h}$ $(P=0.046)$ and naive-FC/24 h groups $(P=0.049)$ (not significant in post-hoc Tukey test, $P=0.110$ and 0.114 , respectively).

In a separate post-hoc experiment, mEPSCs were examined at $3 \mathrm{~h}$ after tone/footshock unpaired training in comparison with naive controls. We found no significant changes in frequency (naive: $1.1 \pm 0.2 \mathrm{~Hz}, n=9$; unpaired: $0.7 \pm 0.2 \mathrm{~Hz}, n=12, t_{19}=1.508$, $P=0.159$ ) or peak amplitude (naive: $21.1 \pm 1.6 \mathrm{pA}, n=9$; unpaired: $\left.22.4 \pm 1.9 \mathrm{pA}, n=12, t_{19}=0.483, P=0.635\right)$. These results suggest that increases of AMPA receptor-mediated synaptic transmission at $3 \mathrm{~h}$ after training are confined to associative learning.

\section{Biochemistry}

In view of the altered mEPSC parameters, we examined whether AMPA receptor subunits (GluR1-3) were modulated by fear conditioning (Fig. 3A). No differences were found in synaptic GluR1, GluR2 or GluR3 expression for the different experimental groups (Fig. 3B, one-way ANOvA; GluR1, $F_{2,21}=1.384, P=0.271$; GluR2, $F_{2,21}=1.414, P=0.257$; GluR3, $F_{2,21}=0.280, P=0.759$ ).

\section{Discussion}

The AMPARs mediate the majority of fast excitatory synaptic transmission in the central nervous system. They help to maintain 


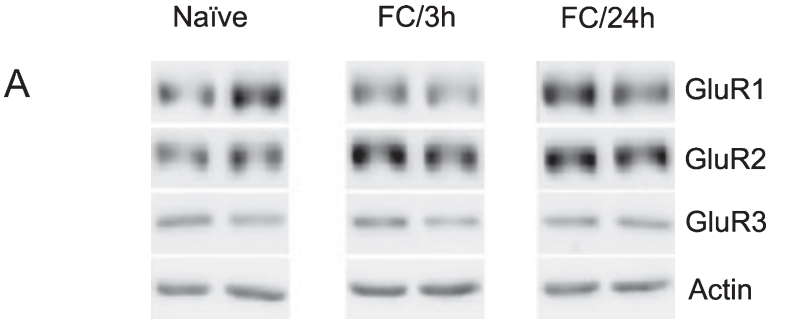

B

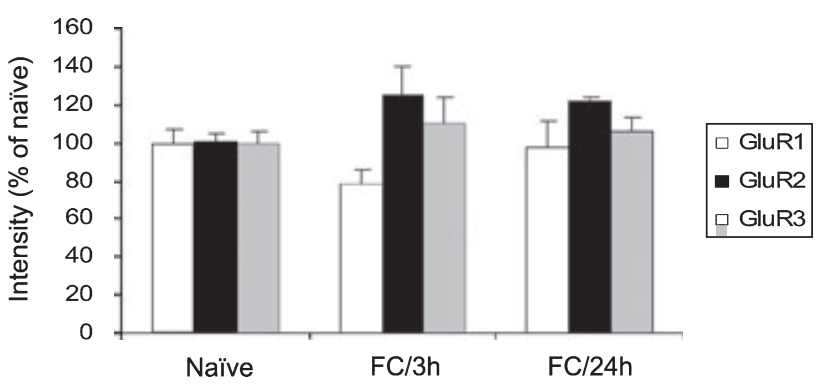

FIG. 3. Synaptic AMPAR subunit expression after fear conditioning. (A) Typical western blot examples (in duplo) of synaptic GluR1-3 and actin expression in naive, $\mathrm{FC} / 3 \mathrm{~h}$ and $\mathrm{FC} / 24 \mathrm{~h}$ groups. (B) Quantification of synaptic GluR1-3 expression in different groups. No significant changes in synaptic AMPAR levels (GluR1-3) were found at 3 and $24 \mathrm{~h}$ after training.

functional connections between synapses that underlie experience/activity-dependent synaptic plasticity (e.g. Malinow \& Malenka, 2002, Takahashi et al., 2003; Benke et al., 1998) and are involved in synaptic strength adjustment in response to previous synaptic activities (Turrigiano et al., 1998).

Activity-dependent changes in functional post-synaptic AMPARs contribute to the two main forms of synaptic plasticity that are believed to underlie learning and memory in the hippocampus (Neves et al., 2008). LTP involves the activity-dependent recruitment of AMPARs to the post-synaptic membrane and a concurrent increase in AMPA-mediated transmission, whereas long-term depression is a decrease in synaptic AMPAR function (Malinow \& Malenka, 2002). Importantly, modifications of synaptic strength have also been observed after learning. Fear conditioning, a strong form of associative learning, is accompanied by enhanced glutamatergic transmission in the subnuclei of the amygdala (McKernan \& Shinnick-Gallagher, 1997; Tsvetkov et al., 2002; Humeau et al., 2007). Moreover, trafficking of AMPA receptors to the post-synaptic membrane in the lateral nucleus of the amygdala is essential for forming fearful memories (Rumpel et al., 2005). Here we report that fear conditioning also enhances spontaneous AMPA receptor-mediated synaptic transmission in the hippocampal CA1 area, implying that changes in synaptic efficacy after fear conditioning are not confined to the amygdala. Although we did not assess learning and electrophysiology in the same animals, as a single retention test may have already influenced the electrophysiological outcome, there is nevertheless strong support for the view that the observed electrophysiological changes are associated with contextual fear learning. First, in the behavioral experiment, all animals (without exception) displayed significantly enhanced freezing at $3 \mathrm{~h}$ after training compared with the pre-shock period, i.e. learned the task; there is no reason to believe that the set of animals used for electrophysiology would respond differently. Second, the increase in synaptic efficacy occurred only in the animals that were trained to associate footshock with context or tone.
The most obvious effect of fear conditioning on AMPAR-mediated mEPSCs turned out to be the transient yet robust increase in mEPSC frequency at $3 \mathrm{~h}$ after training, which suggests a pre-synaptic origin of the changes in synaptic efficacy (e.g. release probability), rather than structural changes, e.g. the generation of new spines, as was reported to occur at $24 \mathrm{~h}$ after fear conditioning (Matsuo et al., 2008). Whether synaptic efficacy after $24 \mathrm{~h}$ has simply returned to its pre-training level or, alternatively, whether long-term depression-like mechanisms have restored synaptic efficacy to pre-training levels (Zhang et al., 2005) needs further investigation. The fact that the current changes in frequency are transient furthermore suggests that they might be related to release rather than structural changes. This would be in line with earlier experiments in the amygdala reporting that cued fear training results in enhanced glutamatergic transmission (McKernan \& Shinnick-Gallagher, 1997), involving enhanced pre-synaptic glutamate release probability as well as post-synaptic changes (Zinebi et al., 2001; Tsvetkov et al., 2002; Humeau et al., 2007).

In agreement with post-synaptic modifications of synaptic efficacy, we observed that fear conditioning slightly enhanced the mEPSC amplitude at $3 \mathrm{~h}$ after training and the same trend remained until at least $24 \mathrm{~h}$. In the adult hippocampus, most AMPARs are heterooligomers, composed of GluR1/GluR2 or GluR2/GluR3 (Wenthold et al., 1996). GluR1/GluR2 receptors are inserted into synapses during synaptic plasticity, whereas GluR2/GluR3 replaces existing synaptic receptors continuously, which is independent of neuronal activity (Shi et al., 2001). Recently, it was reported that passive avoidance training transiently enhanced hippocampal synaptic AMPAR levels with the peak at around 30 min after training (Whitlock et al., 2006). Our biochemical data show no changes in synaptic AMPAR levels per se after training. In this study we used the same synaptoneurosome preparation as described by Whitlock et al. (2006), to enrich for hippocampal synapses. Although this biochemical technique enriches for synaptic proteins, it cannot provide information regarding the composition of AMPARs at the synapse surface. Interestingly, Williams et al. (2007) found time-dependent trafficking of hippocampal synaptic cell surface AMPARs, with an enhancement of GluR2 up to $4 \mathrm{~h}$ post-LTP induction, whereas a corresponding synaptoneurosome preparation was not sensitive enough to detect this change. Although our current data may indicate that alterations in synaptic AMPAR levels after fear conditioning were returned to baseline at $3 \mathrm{~h}$ after training, it is also possible that a more refined analysis of synaptic protein surface expression would uncover a more significant modulation in GluR2.

Several lines of evidence suggest that the production of new proteins is necessary for persistent encoding of recent experiences into long-term memories, whereas modification of existing proteins is required for short-term memory (Davis \& Squire, 1984). We found changes in AMPA receptor-mediated synaptic transmission that occurred most prominently at $3 \mathrm{~h}$ after training. This is in line with the rapid phosphorylation and synaptic incorporation of AMPA receptors as reported earlier (Whitlock et al., 2006). Moreover, preventing synaptic insertion of AMPA receptors inhibits the establishment of fearful memories (Rumpel et al., 2005). The nature of these effects may require the modification of existing receptors and the time-course at which they occur may suggest that the presently described changes in synaptic efficacy are related to short-term memory, although this remains to be verified.

We conclude that fear conditioning enhances synaptic transmission in the hippocampal CA1 area, presumably through both pre- and postsynaptic mechanisms. The findings suggest that the hippocampus is critically involved (in a time-dependent manner) in fear conditioning and support the speculation that the coordinative activity, like theta 
rhythm synchronization, in the amygdala/hippocampal network represents a neuronal correlate of conditioned fear.

\section{Acknowledgements}

This work was supported by grants from the Royal Netherlands Academy of Arts and Sciences (05CDP013) and the Dutch Brain Foundation (13F05.02).

\section{Abbreviations}

AMPAR, AMPA-type glutamate receptor; FC, fear conditioning; GluR2, glutamate receptor 2; LTP, long-term potentiation; mEPSC, miniature excitatory post-synaptic current.

\section{References}

Benke, T.A., Lüthi, A., Isaac, J.T. \& Collingridge, G.L. (1998) Modulation of AMPA receptor unitary conductance by synaptic activity. Nature, 393, 793797.

Davis, H.P. \& Squire, L.R. (1984) Protein synthesis and memory: a review. Psychol. Bull., 96, 518-559.

Humeau, Y., Reisel, D., Johnson, A.W., Borchardt, T., Jensen, V., Geghardt, C., Bosch, V., Gass, P., Bannerman, D.M., Good, M.A., Hvalby, Ø., Sprengel, R. \& Lüthi, A (2007) A pathway-specific function for different AMPA receptor subunits in amygdala long-term potentiation and fear conditioning. $J$. Neurosci., 27, 10947-10956.

Karst, H. \& Joëls, M. (2005) Corticosterone slowly enhances miniature excitatory postsynaptic current amplitude in mice CA1 hippocampal cells J. Neurophysiol., 94, 3479-3486.

LeDoux, J.E. (2000) Emotion circuits in the brain. Annu. Rev. Neurosci., 23, 155-184.

Malinow, R. \& Malenka, R.C. (2002) AMPA receptor trafficking and synaptic plasticity. Аnпu. Rev. Neurosci., 25, 103-126.

Maren, S. (2008) Pavlovian fear conditioning as a behavioral assay for hippocampus and amygdala function: cautions and caveats. Eur. J. Neurosci., 28, 1661-1666.

Matsuo, N., Reijmers, L. \& Mayford, M. (2008) Spine-type-specific recruitment of newly synthesized AMPA receptors with learning. Science, 319 , 1104-1107.

McKernan, M.G. \& Shinnick-Gallagher, P. (1997) Fear conditioning induces a lasting potentiation of synaptic currents in vitro. Nature, 390, 607-611.

Neves, G., Cooke, S.F. \& Bliss, T.V. (2008) Synaptic plasticity, memory and the hippocampus: a neural network approach to causality. Nat Rev Neurosci., 9, 65-75.

Pastalkova, E, Serrano, P, Pinkhasova, D, Wallace, E, Fenton, AA \& Sacktor, TC. (2006) Storage of spatial information by the maintenance mechanism of LTP. Science, 313, 1141-1144.
Plant, K., Pelkey, K.A., Bortolotto, Z.A., Morita, D., Terashima, A., McBain, C.J., Collingridge, G.L. \& Isaac, J.T. (2006) Transient incorporation of native GluR2-lacking AMPA receptors during hippocampal long-term potentiation. Nat Neurosci., 9, 602-604

Rampon, C., Tang, Y.P., Goodhouse, J., Shimizu, E., Kyin, M. \& Tsien, J.Z. (2000) Enrichment induces structural changes and recovery from nonspatial memory deficits in CA1 NMDAR1-knockout mice. Nat Neurosci., 3, 238244.

Rogan, M.T., Stäubli, U.V. \& LeDoux, J.E. (1997) Fear conditioning induces associative long-term potentiation in the amygdala. Nature, 390, 604-607.

Rumpel, S., LeDoux, J., Zador, A. \& Malinow, R. (2005) Postsynaptic receptor trafficking underlying a form of associative learning. Science, $\mathbf{3 0 8}$, 83-88.

Sanders, M.J., Wiltgen, B.J. \& Fanselow, M.S. (2003) The place of the hippocampus in fear conditioning. Eur. J. Pharmacol., 463, 217-223.

Seidenbecher, T., Laxmi, T.R., Stork, O. \& Pape, H.C. (2003) Amygdalar and hippocampal theta rhythm synchronization during fear memory retrieval. Science, 300, 846-850.

Shi, S., Hayashi, Y., Esteban, J.A. \& Malinow, R. (2001) Subunit-specific rules governing AMPA receptor trafficking to synapses in hippocampal pyramidal neurons. Cell, 105, 331-343.

Takahashi, T., Svoboda, K. \& Malinow, R. (2003) Experience strengthening transmission by driving AMPA receptors into synapses. Science, 299, 15851588

Tsvetkov, E., Carlezon, W.A., Benes, F.M., Kandel, E.R. \& Bolshakov, V.Y. (2002) Fear conditioning occludes LTP-induced presynaptic enhancement of synaptic transmission in the cortical pathway to the lateral amygdala. Neuron, 34, 289-300.

Turrigiano, G.G., Leslie, K.R., Desai, N.S., Rutherford, L.C. \& Nelson, S.B. (1998) Activity-dependent scaling of quantal amplitude in neocortical neurons. Nature, 391, 892-896.

Wenthold, R.J., Petralia, R.S., Blahos, J. II \& Niedzielski, A.S. (1996) Evidence for multiple AMPA receptor complexes in hippocampal CA1/CA2 neurons. J. Neurosci., 16, 1982-1989.

Whitlock, J.R., Heynen, A.J., Shuler, M.G. \& Bear, M.F. (2006) Learning induces long-term potentiation in the hippocampus. Science, 313, 1093 1097.

Williams, J.M., Guévremont, D., Mason-Parker, S.E., Luxmanan, C., Tate, W.P. \& Abraham, W.C. (2007) Differential trafficking of AMPA and NMDA receptors during long-term potentiation in awake adult animals. $J$. Neurosci., 27, 14171-14178

Zhang, J., Yang, Y., Li, H., Cao, J. \& Xu, L. (2005) Amplitude/frequency of spontaneous mEPSC correlates to the degree of long-term depression in the CA1 region of the hippocampal slice. Brain Res., 1050, 110 117.

Zinebi, F., Russell, R.T., McKernan, M. \& Shinnick-Gallagher, P. (2001) Comparison of paired-pulse facilitation of AMPA and NMDA synaptic currents in the lateral amygdala. Synapse, 42, 115-127. 